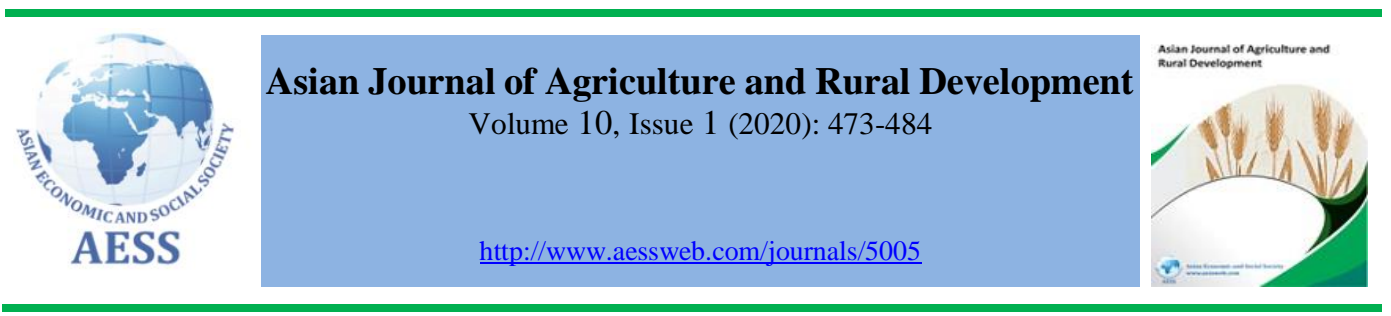

\title{
VOCATIONAL TRAINING FOR RURAL WORKERS IN THE CONTEXT OF ECONOMIC RESTRUCTURING IN HA TINH PROVINCE, VIETNAM
}

\author{
Bui Thi Quynh Tho ${ }^{a}{ }^{a}$ Ha Tinh University, Vietnam \\ Nguyen Thi Kim Nhung a \\ Tran Hai Ngoc a \\ \ $₫$ tho.buithiquynh@htu.edu.vn (Corresponding author) \\ Tran Thi Khanh ${ }^{\text {a }}$
}

\section{ARTICLE HISTORY: \\ Received: 19-Mar-2020 \\ Accepted: 21-May-2020 \\ Online Available: $27-J u n-$ \\ 2020}

\section{Keywords:}

Rural worker,

Vocational training,

Economic structure,

Economic restructuring

\begin{abstract}
Labor force development is one of the strategic solutions in the process of shifting the agricultural and rural economy to commodity production in accordance with economic restructuring. The article aims at discussing the trend of economic restructuring in Ha Tinh province in recent years, surveying vocational training needs of rural workers and vocational training results in $\mathrm{Ha}$ Tinh province in the context of economic restructuring. The research utilizes a binary logit model for primary data collected in a sample of 334 working-age people in Ha Tinh province to examine the vocational training needs of rural laborers in Ha Tinh. It is found that economic restructuring and state policies have a significant effect on the vocational training needs of rural workers. In addition, the change in vocational training pattern is relatively in line with the change in economic restructuring. The study also gives some recommendations for rural vocational training policy in Ha Tinh province.
\end{abstract}

\section{Contribution/ Originality}

This is the first study to examine vocational training needs for rural workers in the context of economic restructuring in Ha Tinh province, Vietnam. It employs Binary Logit Model to identify factors influencing the vocational training needs of rural workers. The study goes further by assessing some results on vocational training for rural laborers in $\mathrm{Ha}$ Tinh and giving some recommendations for developing vocational training policies for rural workers in Ha Tin Province, Vietnam.

DOI: $10.18488 /$ journal.1005/2020.10.1/1005.1.473.484

ISSN (P): 2304-1455/ISSN (E):2224-4433

How to cite: Bui Thi Quynh Tho, Nguyen Thi Kim Nhung, Tran Hai Ngoc and Tran Thi Khanh (2020). Vocational training for rural workers in the context of economic restructuring in Ha Tinh province, Vietnam. Asian Journal of Agriculture and Rural Development, 10(1), 473-484.

(C) 2020 Asian Economic and Social Society. All rights reserved. 


\section{INTRODUCTION}

Vocational education and training play an important role in productivity improvement, providing human capital for economic development and sustainability (Atchoarena and Gasperini, 2003; Fluitman, 2002; Hilal, 2012; Wallenborn, 2014). According to Fluitman (2002), skill training can contribute to quality and output increase, health improvement, job security, hence improving the income and employability of the poor in the informal sector. Particularly, in rural areas, vocational education and training is the key to rural employment and poverty reduction. Rural workers with higher education training can have higher productivity (Atchoarena and Gasperini, 2003).

As the case of Vietnam, vocational training contributes to the increase in productivity of the rice sector in Vietnam (Ulimwengu and Badiane, 2010). Using household survey data, Ulimwengu and Badiane (2010) studied the relationship between farmer's education attainment and agricultural productivity in Vietnam, controlling for gender and worker health. The research found that as long as poor farmers are trained in specific technical needs, agricultural productivity will be improved. It also pointed out the necessity of adjusting the training non-traditional education curricular in order to meet the skill needs of workers in rural areas. Some research focuses on the vocation training for rural youth in Vietnam. Using survey data from 3 provinces in Vietnam, Pham and Le (2017) found that rural youths with vocational training have more advantages over those without vocational training when finding sustainable jobs. Institute of Labour Science and Social Affairs (2017) pointed out the needs of vocational training needs for youth in rural areas of Vietnam to meet the demand of economic development.

Like many rural areas in Vietnam, Ha Tinh province has an extremely abundant labor resource. Ha Tinh has a population of 1,277,530 people in 2018, among these, there are 239,643 people in the urban area, 1,037,887 people in the rural area. The number of people living in rural area makes up 81.24\%. However, human resources in rural areas in Ha Tinh are still facing many shortcomings such as poor education, low professional qualifications, unequal labor distribution, which limits the initiative and creativity in production as well as technology application and market access. Also, the low level of awareness and small production practices significantly affect the quality and structure of labor. This leads to labor inefficiency, low production, difficulties in applying modern technology, narrow market, low competitiveness. When economic restructuring in Ha Tinh tends to shift from agriculture to industry and service with more specialization, the demand for labors in agriculture decreases while that in industry and sector increases. Therefore, it is important to provide vocational training for rural workers so that they can have better employment opportunities. In addition, in Ha Tinh in general and in Vietnam in particular, vocational training for rural workers is an important criterion in new rural area construction in Vietnam.

\section{LITERATURE REVIEW}

Depending on the context and purpose, there are different approaches to examining vocational training for rural laborers in countries. Along with institutions, the state policies, including policies for training human resources, play an active role in promoting economic restructuring. From the perspective of Colin (2005), reform or change the production structure contributes to achieving economic growth, in which the adjustment of macroeconomics plays an important role.

Gylfason et al. (1999) tried to quantify the effects of economic restructuring on the growth of countries around the world by examining the change in the share of GDP in agriculture and the shift of migrant workers from rural to urban areas. In addition to studying the direct effect of the change in the share of agriculture in GDP on economic growth, Gylfason et al. (1999) also examined the shift immigrant worker from rural to the urban area. Thus, vocational training for rural workers must be based on the economic restructuring of each country. 
One of the most visible characteristics of rural labor is lower qualification than urban labor. Atkinson (2005) pointed out the causes of the stagnancy in industrial development, the lack of intellectual labor force, or poor infrastructure. At the same time, the author outlined six things that the government should do to revitalize the rural area in America. Instead of just financing the rural area, the government must help workers in rural areas switch jobs. Vocational training for rural workers is one of the policies to speed up career change.

Researching training, recruiting, and developing technical human resources in Korea and Thailand, Hawley and Paek (2005) found that Korea implemented flexible and diversified recruitment subjects. In addition to recruiting new graduates, businesses and government agencies also welcome international workers and students to Korea. Many of them are rural workers from developing countries. In Thailand, the vocational training system is always oriented towards socioeconomic development and poverty reduction based on training opportunities, training quality, and competitiveness of the economy. Therefore, the vocational training policy in Thailand always creates favorable conditions for all participants in vocational training without taking entrance exams, preferential treatment for disabled apprentices, focusing on supporting career orientation as well as coordinating with enterprises in recruiting, creating jobs for skilled workers. In addition, the system of vocational schools in Thailand has developed thanks to the trend of "socialization", which means there is an equal development in vocational schools in both public and those in private sectors.

Tarp (2017) has important research on Growth, Structural Transformation, and Rural Change in Viet Nam. On the one hand, Tarp (2017) provided a comprehensive understanding of the impact of rural household access to markets for land, labour, and capital. Tarp (2017) also elaborated on government policies on growth, inequality, and poverty at the village level in Viet Nam. The research pointed out how gains and losses form economic growth is distributed. The research provided a comprehensive set of materials and studies of use to academics, students and development practitioners who are keen on an integrated approach to the study of growth, structural transformation, and the microeconomic analysis of development in a developing country.

In Vietnam, several studies have examined vocational training for rural workers and their role in the process of economic restructuring. These studies emphasize the role of vocational training for rural laborers as an urgent solution to meet the demand of economic structuring (Le, 2001; Nguyen, 2012; Pham, 2001). These studies separate vocational training for rural workers and economic restructuring. For the research on vocational training, they are mostly related to the proposed solution to improve the effectiveness of vocational training for rural workers. Meanwhile, for studies on economic restructuring, authors have integrated vocational training for labor into solutions to develop human resources. There have been few studies on vocational training for rural workers in line with economic restructuring. This study makes a modest contribution to the existing literature by studying the current situation of vocational training for rural workers in Ha Tinh Province (Vietnam) considering economic restructuring.

\section{DATA AND METHODOLOGY}

\subsection{Data}

This research utilizes both secondary data and primary data. The primary data is collected to examine the vocational training needs of rural workers. The authors got this data by conducting surveys among a sample of 334 working-age people in some rural areas in Ha Tinh province. The variables used in this study are (i) training needs of rural workers; (ii) age of correspondent; (iii) Education attainment; (iv) household size; (v) average household income; (vi) state vocational training policies: (vii) economic restructuring. 
The secondary data on the economic restructuring and economic performance of Ha Tinh province, the employment situation of trained rural workers are collected from Ha Tinh Statistical Office and Ha Tinh Department of Labor - Invalids and Social Affairs.

\subsection{Econometric technique}

To study the vocational training needs of workers, the authors use a logistic regression model to quantify the influence of factors on the probability of rural laborers having vocational training needs. Data are collected through a sociological survey, participatory rural appraisal (PRA) method, and then processed by Excel, EVIEWS, and synthesized. This study uses the Binary Logistic regression model to analyze the factors affecting rural workers' vocational training needs.

Binary Logistic non-linear regression model is used to determine the impact of $\mathrm{Xi}$ factors on the probability of $\mathrm{Y}$ when $\mathrm{X}$ occurs. In Logistic regression, dependent variables are binary while independent variables can be continuous, binary, or categorical. The inverse of the standardized probability distribution function is a linear combination of explanatory variables. In this model, the left side of the logistic function is a dependent variable that receives 2 values: equal to 0 (if the laborer does not need vocational training) and equal to 1 (if the laborer needs vocational training). The right side of the equation consists of 3 different groups of variables including personal characteristics, household characteristics, and state vocational training policies.

The regression model is as follows:

$P_{i}=\frac{e^{X_{i} \beta}}{1+e^{X_{i} \beta}}\left(\right.$ where: $X_{i}=\left(1 ; X_{1 i} ; X_{2 i} ; X_{3 i} ; X_{4 i} ; X_{5 i} ; X_{6 i} ;\right), \beta=\left(\beta_{0} ; \beta_{1} ; \beta_{2} ; \beta_{3} ; \beta_{4} ; \beta_{5} ; \beta_{6}\right)$

or:

$\log _{e} P(Y=1) / P(Y=0)=\beta_{0}+\beta_{1} X_{1}+\beta_{2} X_{2}+\beta_{3} X_{3}+\beta_{4} X_{4}+\beta_{5} X_{5}+\beta_{6} X_{6}$

(1) $\mathrm{X}_{1}$ : Age of the correspondent

(2) $X_{2}$ : Education attainment

(3) $\mathrm{X}_{3}$ : Household size (number of people in the household)

(4) $\mathrm{X}_{4}$ : Average household income (million dong)

(5) $\mathrm{X}_{5}$ : Effect of state vocational training policies

(6) $\mathrm{X}_{6}$ : Effect of econonomic restructuring

Dependent variable $=\mathrm{Y}($ binary variable $)$

$\mathrm{Y}=\quad$ 1: Have vocational training needs

0: Have no vocational training needs

This model consists of 6 independent variables that explain the probabilities of rural laborers having vocational training needs.

In this model, when $X_{i} \beta$ receives a value from $-\infty$ to $+\infty$, Pi receives a value from 0 to 1 . The function is nonlinear with both $\mathrm{X}$ and the parameter $\beta$, so the maximum likelihood estimation method is used to estimate the parameters. After estimating the parameters, the sample regression model will be:

$$
\hat{P}_{i}=\frac{\exp ^{X_{i} \widehat{\beta}}}{1+\exp ^{X_{i} \widehat{\beta}}}
$$

This model shows the effect of the variables Xi on the probability that $\mathrm{Y}$ will get the value of 1 . In other words, this model shows the probability that the $i^{\text {th }}$-person in the sample needs vocational training, considering the influence of some factors. 


\section{RESEARCH RESULTS AND DISCUSSION}

\subsection{Economic restructuring in Ha Tinh province}

The economic structure of Ha Tinh province changes in the direction of reducing the proportion of agriculture, forestry, and fisheries and increasing the proportion of the industry, construction, trade, and services.

Table 1: Percentage economic structure of Ha Tinh province in the period of 2015-2019

\begin{tabular}{cccc}
\hline Year & Agriculture, Forestry and Fishery & Industry-Construction & Trade and Service \\
\hline 2015 & 18.13 & 38.05 & 43.82 \\
2016 & 22.69 & 32.07 & 45.24 \\
2017 & 15.54 & 44.05 & 40.41 \\
2018 & 15.28 & 43.79 & 40.93 \\
2019 & 13.63 & 43.22 & 43.15 \\
\hline
\end{tabular}

Source: Ha Tinh Statistical Office, 2020

\subsection{Agriculture, Forestry and fishery}

The agricultural structure has been positively shifting towards promoting the advantages of key agricultural products of each locality to meet market demand. Some key agricultural products of Ha Tinh include Phuc Trach-Huong Khe grapefruit, Khe May oranges, fresh deer velvet, dried deer antler and processed products from deer velvet in Huong Son District, vegetable growing areas in communes such as Tuong Son, Thien Loc, Thach Lien, other riverside areas in Duc Tho and Huong Son districts. Many technical advances and new technologies have been transferred and applied in production, contributing to increased productivity, quality and economic efficiency in Ha Tinh such as: Applying specialized technology of breeding beef cattle; on-sand shrimp farming, super lean pigs raising. Many businesses, cooperatives and production complexes with advanced technology were established, contributing to minimize market-related risks.

The agricultural structure in Ha Tinh not only changes in the proportion of sub-sectors, but the value chain of agricultural products has been increased by reorganizing production and linking with enterprises. From 2011 to 2015, 2016-2020, thanks to implementing agricultural restructuring policy, Ha Tinh has attracted many businesses to invest in agriculture, forestry and fisheries. Many efficient production models have been established in the province.

\subsection{Industry}

Industry increasingly accounts for a large proportion and experiences rapid development. The change in the industrial structure is also indicated by the increase in the value of processed and manufactured products. Industry focuses more on processing agriculture, forestry and fisheries products, mining, manufacturing of construction materials, metallurgy, electricity and mechanics. Processing and manufacturing industries are often scattered in different areas of the province. Generally, Ha Tinh industrial production index in the period of 2014-2018 increased annually. The processing and manufacturing industry plays a key role in leading the overall growth of the industry and the whole economy. However, there has not been profound industrial development in the province. There are also limitations in connecting with other provinces in the region in terms of developing a value chain and logistics system, attracting investment in infrastructure construction and economic zones. The process of restructuring industrial sectors is still slow, not making significant changes in the intra-industry structure.

\subsection{Trade and services}

Trade and service sector has experienced stable development, ranging between $40 \%$ and $45 \%$ growth speed in recent years. The consumption market as well as the supply of goods has been 
expanded. More types of retail service such as mini supermarkets and convenience store chains have gradually appeared in rural areas.

In general, economic restructuring has shifted towards increasing the proportion of industry and service sectors, reducing that of agriculture, forestry and fishery. The industry has had a breakthrough development. Supporting industries, new energy industries, manufacturing and processing industry have started to develop. Service and trade have a quick recovery. Despite economic shocks and unfavorable incidents, the service sector has prospered and increasingly met the changing demand of the society. The economic restructuring has a significant impact on rural labourer's vocational training needs, vocational training institutions as well as vocational training policies issued by the state.

Labor structure and economic structure are closely related. When the economic structure changes, it means changing the proportion of sectors in the economy. Resources will be shifted from sectors with decreasing proportion to sectors with increasing proportion. Therefore, when the economic transition takes place, it will change the proportion of the labor force (a kind of resource) in sectors Labor will shift from the sector with the decreasing proportion (labor surplus) to the industry with the increasing proportion (labor shortage), thus leading to the restructuring of labor structure. Today, with the continuous development of science and technology, the industry and service industry sector is constantly developing. Therefore, the change in the proportion of these sectors will result in the labour transition. More labours in the agricultural sector will be attracted to the industry and service sector. Structural transformation often takes place first and orientates labor restructuring. Meanwhile, vocational training for rural laborers changes the structure of rural laborers. Therefore, vocational training for rural laborers has a close relationship with economic restructuring.

\subsection{Vocational training needs of rural laborers in the context of economic restructuring} In the context of Ha Tinh's economic restructuring, there is a shift among sectors and fields. To investigate the factors affecting the vocational training needs of rural laborers, the research team surveyed working-age rural laborers. Factors that influence vocational training needs are divided into internal factors and external factors. Internal factors include educational attainment, age of workers, household size, family's economic status...External factors are information on training programs provided by institutions, local authorities, society, State training policies... Based on the regression model in section 3.2, the result is presented in table 2.

Table 2: Logistics model results using Eviews software

\begin{tabular}{|c|c|c|c|c|c|}
\hline No. & Independent variable & Coefficient & Std. Error & Z-statistic & Prob. \\
\hline 1 & Intercept $(\mathrm{C})$ & -33.974 & 7.549 & -4.500 & $0.000 *$ \\
\hline 2 & Age (X1) & -0.136 & 0.046 & -2.931 & $0.003 *$ \\
\hline 3 & Educational attainment (X2) & -0.631 & 0.363 & -1.734 & $0.083 * * *$ \\
\hline 4 & Household size (X3) & 0.993 & 0.792 & 1.253 & $0.209 * * *$ \\
\hline 5 & Average household income (X4) & 0.632 & 0.142 & 4.431 & $0.000 *$ \\
\hline 6 & State policy (X5) & 2.089 & 0.821 & 2.544 & $0.011 * *$ \\
\hline 7 & Economic restructuring (X6) & 2.337 & 0.968 & 2.414 & $0.015^{* *}$ \\
\hline
\end{tabular}

Note: $* * *$, and $* * *$ represents $1 \%, 5 \%$, and $10 \%$ level of significance respectively

The regression model is as follow:

$\log _{\mathrm{e}} \mathrm{P}(\mathrm{Y}=1) / \mathrm{P}(\mathrm{Y}=0)=-33.974-0.136 * \mathrm{X}_{1}-0.631 * \mathrm{X}_{2}+0.993 * \mathrm{X}_{3}+0.632 * \mathrm{X}_{4}+2.089 * \mathrm{X}_{5}+$ $2.337 * \mathrm{X}_{6}$

Age (X1) has a negative effect on vocational training needs. The older the labors are, the less they want to participate in vocational training. Therefore, vocational training policies should focus on 
youths who are more likely to pursue vocational training. This result is similar to Pham and Le (2017), Yu and Wang (2014). However, in terms of education attainment (X2), this research is contradictory to Pham and Le (2017). The negative coefficient on education attainment shows that highly educated workers face relatively higher opportunity costs for changing jobs so they are less likely to take up vocational training. Meanwhile, household size (X3), average household income (X4) have a slight positive effect on vocational training needs. State policies and economic restructuring have the greatest effect on vocational training needs.

- Variable X5 (State policies): The p_value of the coefficient on X5 $\left(\hat{\beta}_{5}\right)$ is $0.0109(<0.05)$ so $\hat{\beta}_{5}$ is significant at the $5 \%$ level. This result shows that state vocational training policies affect the vocational training needs of rural workers. With the state's supporting policy, especially related to tuition fees, rural laborers are encouraged to study in various vocational fields. $\hat{\beta}_{5}=2,089$ shows that the increase in the correspondent's perception about state policies (holding other factors constant) will lead to a 0.889 increase in the probability of rural laborers having vocational training needs. According to descriptive statistics, the mean value of opinions about vocational training needs is 3.8, which means state policies have a great influence on vocational training needs. $70.3 \%$ of the correspondents held this opinion.

- Variable (X6): The p_value of the coefficient on X6 $\left(\hat{\beta}_{6}\right)$ is $0.0158(<0.05)$ so $\hat{\beta}_{6}$ is significant at the $5 \%$ level. $\hat{\beta}_{6}=2.3374$ shows economic restructuring has a positive effect on vocational training needs. The trend of economic restructuring is increasing the proportion of industry and service and gradually reducing the proportion of agriculture. Since then, the labor force in industry and service also shifts, increasing the proportion of industrial and service workers and reducing the proportion of agricultural labor. Along with economic development, industrial zones, businesses and resorts will attract more and more laborers, thereby increasing the vocational training needs in the industry and service sector. The coefficient $\hat{\beta}_{6}=2.3374$ indicates that, if workers increase their perception of the impact of economic restructuring on vocational training needs (other factors are constant), there will be a 0.56 increase in the probability for them to have vocational training needs. According to descriptive statistics, on average, all respondents thought that the economic restructuring process has a great impact on vocational training needs (the mean value is 3.86 ), and nearly $80 \%$ of respondents hold this opinion.

Table 3: Descriptive statistics describing perception about the influence of state policies and economic restructuring on vocational training needs

\begin{tabular}{lcccccc}
\hline Mean value & $\begin{array}{c}\text { Have no } \\
\text { effect } \\
(\boldsymbol{\%})\end{array}$ & $\begin{array}{c}\text { Have small } \\
\text { effect } \\
(\boldsymbol{\%})\end{array}$ & $\begin{array}{c}\text { Have } \\
\text { moderate } \\
\text { effect }(\boldsymbol{\%})\end{array}$ & $\begin{array}{c}\text { Have big } \\
\text { effect } \\
(\boldsymbol{\%})\end{array}$ & $\begin{array}{c}\text { Have very } \\
\text { big effect } \\
(\boldsymbol{\%})\end{array}$ \\
\hline $\begin{array}{l}\text { State policies } \\
\text { Economic } \\
\text { restructuring }\end{array}$ & 3.8 & 0 & 0.90 & 23.4 & 70.3 & 5.4 \\
\hline
\end{tabular}

Source: Authors' own calculations

The obtained Binary Logistic regression model shows that the 2-loglikelihood index is -22.049 which is an appropriate indicator to confirm the certainty of the model. The McFadden R-squared correlation coefficient is 0.876 , indicating that $87.69 \%$ of the change in vocational training needs is explained by the factors within the model.

The Homer and Lemeshow tests show that the Chi-Squares value is 10.595 with [Prob.] $=0.997$ (> 0.05), proving that the model is in the right form. These results all show that the Binary Logistic regression model is suitable and can be applied in the analysis. The actual survey results show that $77.3 \%$ of the respondents have vocational training needs soon, focusing mainly on those who are young or are not yet apprenticed. 
With regard to the survey on vocational training needs, when requested to identify a vocational training area in which they are interested in pursuing, 224 out of 334 working-age correspondents in rural areas chose the industry and service sector, accounting for $51.8 \%$ and $39.3 \%$ respectively. Only $8.9 \%$ correspondents wanted to be trained in the agriculture sector. The high demand for industry and service training among rural workers is consistent with economic restructuring and development.

After determining the factors affecting workers 'vocational training needs, including economic restructuring, the research team investigated the employment needs of students who are currently studying at vocational schools. The results show that $45 \%$ of learners want to work in industry and construction after graduation; $45.7 \%$ would like to work in the service sector; Only $5.4 \%$ are keen on working in agriculture, forestry and fishery. Once again, the results show that the vocational training needs of learners are in line with the trend of economic restructuring.

\subsection{Policies and objectives of vocational training for rural workers consistent with the economic restructuring in Ha Tinh province}

Being aware of the important role of vocational training, especially in the context of economic restructuring, the Government has issued many guidelines and policies to encourage vocational training for rural workers such as Decision 1956/2009/QDTTg approving the Project on Vocational Training for Rural Laborers until 2020 (Project 1956). Accordingly, the People's Council of Ha Tinh Province issued Resolution 56/2017/NQ-HDND to implement the Prime Minister's Decision 1956 on vocational training for rural labor for the 2017-2020 period. In this resolution, the target number of trainees is 70,000 in the 2011-2015 period, 80,000 people in the 2016-2020 period. In total, Ha Tinh province targets to have 150,000 new trained rural laborer by 2020 .

From 2012 to 2019, the proportion of the labor force in rural areas accounted for over $80 \%$ of the total labor force. However, in terms of labor structure by sectors, there has been a clear shift with the increasing proportion of industry and service sector compared to a decreasing share of agriculture forestry and fishery sector (Table 4).

Table 4: Sector-wise structure of working age (above 15) population

\begin{tabular}{cccccccc}
\hline \multirow{2}{*}{ Year } & \multicolumn{2}{c}{$\begin{array}{c}\text { Agriculture - Forestry - } \\
\text { Fishery }\end{array}$} & \multicolumn{2}{c}{ Industry - Construction } & \multicolumn{2}{c}{ Trade -Service } & \multirow{2}{*}{ Total } \\
\cline { 2 - 7 } & No. of people & $\begin{array}{c}\text { Share } \\
(\boldsymbol{\%})\end{array}$ & No. of people & $\begin{array}{c}\text { Share } \\
(\boldsymbol{\%})\end{array}$ & No. of people & $\begin{array}{c}\text { Share } \\
(\boldsymbol{\%})\end{array}$ \\
\hline 2017 & 387,423 & 54.81 & 102,605 & 14.51 & 216,862 & 30.68 & 696,978 \\
2018 & 320,460 & 45.04 & 157,693 & 22.17 & 233,297 & 32.79 & 711,450 \\
2019 & 300,049 & 43.05 & 165,290 & 23.72 & 231,639 & 33.23 & 706,890 \\
\hline
\end{tabular}

Source: Ha Tinh Department of Labor - Invalids and Social Affairs

\subsection{Results of vocational training for rural workers in Ha Tinh province in the context of economic restructuring}

The total number of labor force admitted to vocational training for the period $2010-2018$ is 59,313 people. The details are as follows:

- Period of 2010-2015: The total number of trained rural laborers is 38,575 people. In which: basic training 21,425 people, accounting for 56\%; training for less than 3 months is 17,150 people, accounting for $44 \%$. The total number of rural laborers who are supported with basic training and training for less than 3 months according to the policy specified in Decision No. 1956/QD-TTg is 37,375 people; in which the number of people supported for agricultural vocational training is 22,799 people, accounting for $61 \%$; the number of people supported with non-agricultural vocational training is 14,576 people, accounting for $39 \%$. 
- Period of 2016 - 2018: The total number of trained rural laborers is 20,738 people. In which: primary training 11,743 people, accounting for $57 \%$; under 3 -month training is 8,995 people, accounting for $43 \%$. The total number of rural laborers who are supported with basic training and training for less than 3 months under the policy specified in Decision No. 46/2015/QD-TTg is 16,283 people; in which the number of people supported with agricultural vocational training is 6,276 people, accounting for $39 \%$; the number of people supported with non-agricultural vocational training is 10,007 , accounting for $61 \%$.

- In the first 6 months of 2019, the number of trained rural laborers is 5,445 people. In which: 3,950 people at primary education, accounting for $73 \%$; training for less than 3 months is 1,495 people, accounting for $27 \%$. The number of rural laborers who are supported with primary training and under 3 months training according to the policy specified in Decision No. 46/2015/QD-TTg is 1,677 people; in which the number of people supported for agricultural vocational training is 757 , accounting for $45 \%$; 920 people are supported for non-agricultural vocational training, accounting for $55 \%$.

Regarding the structure of training occupations under Project 1956, the structure of trained occupations gradually shifted to increase the proportion of non-agricultural vocational training and reduce the proportion of agricultural vocational training. The change in vocational training structure is suitable for economic restructuring.

\subsection{Evaluate training effectiveness}

For the period 2010-2015, the province targeted to train 32,000 workers with $70 \%$ of those having a job after training. Ha Tinh had trained 37,375 people, exceeding $16.8 \%$ of the set target, the rate of employed labor exceeds 70\% (Table 5). For the period 2016-2020, the target of training was 32,000 workers in Ha Tinh province, the percentage of employed laborers was at least $80 \%$. In the period of 2016-2018, Ha Tinh had trained 16,283 employees; the rate of employed labor reached a minimum of $80 \%$. In particular, the proportion of employed labor in agriculture was higher than that of non-agricultural employment. In general, the training program for rural laborers in Ha Tinh had achieved the goals set for each period. However, during the period 2010-2018, the proportion of employed labor in the non-agricultural sector was only 59.5\%. This requires policies to promote and find jobs for workers.

Table 5: The employment situation of rural workers after apprenticeship

\begin{tabular}{|c|c|c|c|c|c|c|c|c|c|}
\hline \multirow[b]{2}{*}{ Period } & \multicolumn{3}{|c|}{ No. of trainees } & \multicolumn{3}{|c|}{ No. of employed } & \multicolumn{3}{|c|}{ Share of employed labor } \\
\hline & Total & Agriculture & $\begin{array}{l}\text { Non- } \\
\text { agriculture }\end{array}$ & Total & Agriculture & $\begin{array}{l}\text { Non- } \\
\text { agriculture }\end{array}$ & Total & Agriculture & $\begin{array}{l}\text { Non- } \\
\text { agriculture }\end{array}$ \\
\hline $\begin{array}{l}2010- \\
2018\end{array}$ & 53,658 & 29,075 & 24,583 & 41,330 & 26,700 & 14,630 & $77 \%$ & $91.8 \%$ & $59.5 \%$ \\
\hline $\begin{array}{l}2010- \\
2015\end{array}$ & 37,375 & 22,799 & 14,576 & 28,150 & 17,950 & 10,200 & $75.3 \%$ & $78.7 \%$ & $70 \%$ \\
\hline $\begin{array}{l}2016- \\
2018\end{array}$ & 16,283 & 6,276 & 10,007 & 13,180 & 8,750 & 4,430 & $80.9 \%$ & - & - \\
\hline 2019 & 4,500 & 2,000 & 2,500 & 3,700 & 1,800 & 1,900 & $82.2 \%$ & $90 \%$ & $76 \%$ \\
\hline
\end{tabular}

Source: Ha Tinh Department of Labor - Invalids and Social Affairs (2019)

Regarding the types of jobs that employees participated in after training, in the period of 2010 $2020,22,200 / 41,330$ employees will continue to do the same jobs but their labor productivity and income increase, accounting for $53.7 \%$ of the total number of employees. I In addition, a number of rural laborers work in other forms such as: working under labor contracts with enterprises, signing products off-take agreements with enterprises, setting up their own enterprises, cooperatives, cooperative groups, production groups. 
Table 6: Job wise distribution of rural workers

\begin{tabular}{lcccc}
\hline Expression & $\mathbf{2 0 1 0 - 2 0 1 8}$ & $\mathbf{2 0 1 0 - 2 0 1 5}$ & $\mathbf{2 0 1 6 - 2 0 1 8}$ & $\mathbf{2 0 1 9}$ \\
\hline $\begin{array}{l}\text { Rural laborers are recruited by } \\
\text { enterprises to work under labor } \\
\text { contracts }\end{array}$ & 5,400 & 3,850 & 1,550 & 600 \\
$\begin{array}{l}\text { Rural laborers are contracted to } \\
\text { cover products }\end{array}$ & 5,880 & 4,090 & 1,790 & 500 \\
$\begin{array}{l}\text { Rural laborers continue to do } \\
\text { previous jobs but with increasing } \\
\text { productivity and income }\end{array}$ & 22,200 & 14,500 & 7,700 & 2,200 \\
$\begin{array}{l}\text { Rural laborers are allowed to } \\
\text { establish } \\
\text { cooperatives, } \\
\text { groups, production groups } \\
\text { Total cooperative }\end{array}$ & 7,850 & 5,710 & 2,140 & 400 \\
\hline
\end{tabular}

Source: Ha Tinh Department of Labor - Invalids and Social Affairs (2019)

In the period from 2010 to 2018 , there is a large proportion of rural laborers who continue to do previous jobs but with increasing productivity and income (22,200 people, accounting for $53.7 \%$ of the total number of employees in rural areas), in 2019 this figure was 59.5\%; followed by selfemployment through establishing businesses, cooperatives, cooperative groups, production groups (7,850 people, accounting for nearly $19 \%)$. The rest work in enterprises under labor contracts or being signed contracts to cover products by enterprises.

\section{CONCLUSION}

This research has examined the current situation of vocational training for rural workers in Ha Tinh Province in the context of economic restructuring. The result from the binary logit model shows that economic restructuring and state policies have a large effect on the vocational training needs of rural workers. Overall, Ha Tinh is one of the localities that have well-implemented vocational training policies for rural laborers. From basic short-term training (less than 3 months) to intermediate and college training at vocational training institutions, Ha Tinh has well exploited the government's support policies to promote the effectiveness of training and retraining for rural laborers.

However, because the training support policy for rural labor is mainly short-term, training results sometimes fail to meet some expectations. The results of short-term vocational training are still formalistic. For medium and long-term training disciplines (intermediate, college), some professions require high technology; specialized-skills such as welding, industrial electricity, and electronics do not attract students despite the high demand. Meanwhile, some professions such as accounting, sewing, and tourism are attractive to students because these areas are less laborintensive.

The current supporting policies for rural labor force will expire in 2020, suggesting that the Government need other policies to replace them promptly. In addition, when developing vocational training policies for rural laborers, it is necessary to research and consider the trend of movement among sectors and fields, thereby prioritizing funding support for sectors with market demand. This will promote the efficiency of the Government's investment in training, developing quality human resources, and meeting job requirements most effectively as well as adapting to the shift of economic structure in the current period. 
Funding: This study did not receive any specific financial support.

Competing Interests: The authors declared that they have no conflict of interests.

Contributors/Acknowledgement: All authors participated equally in designing and estimation of current research.

Views and opinions expressed in this study are the views and opinions of the authors, Asian Journal of Agriculture and Rural Development shall not be responsible or answerable for any loss, damage or liability, etc. caused in relation to/arising out of the use of the content.

\section{References}

Atchoarena, D. E., \& Gasperini, L. E. (2003). Education for rural development towards new policy responses. In S. United Nations Educational, P. Cultural Organization, F. United Nations, \& R. Agriculture Organization (Eds.): International Institute for Educational Planning (IIEP) UNESCO.

Atkinson, R. (2005). The new rural development challenge: Rivitalizing rural America. Retrieved from http://www.csg.org/pubs/Documents/BOS2005-RuralDevelpmnt.pdf.

Colin, I. B. J. (2005). Prioritizing economic growth: enhancing macroeconomic policy choice (Vol. 37): United Nations Conference on Trade and Development. New York and Geneva, April 2005 Retrieved from https://unctad.org/en/docs/gdsmdpbg2420054_en.pdf

Fluitman, F. (2002). Unpublished plenary discussion on the draft of the world bank's vocational skills development in Sub-saharan Africa: synthesis of a regional review. University in Edinburgh, Scotland

Gylfason, T., Herbertsson, T. T., \& Zoega, G. (1999). A mixed blessing natural resources and economic growth. Macroecon. Dynam., 3(2), 204-225. doi:10.1017/S1365100599011049.

Ha Tinh Department of Labor - Invalids and Social Affairs. (2019). Report on vocational training for rural workers 2017-2019. Government of Vietnam.

Ha Tinh Statistical Office (2020). Statistical Yearbook 2015- 2019. Government of Vietnam. Retrieved from http://thongkehatinh.gov.vn/

Hawley, J. D., \& Paek, J. (2005). Developing human resources for the technical workforce: a comparative study of Korea and Thailand. International Journal of Training and Development, 9(1), 79-94. doi:10.1111/j.1360-3736.2005.00223.x

Hilal, R. (2012). Vocational Education and Training for women and youth in Palestine: Poverty reduction and gender equality under occupation. International Journal of Educational Development, 32(5), 686-695. doi:10.1016/j.ijedudev.2012.02.008.

Institute of Labour Science and Social Affairs (2017). Vocational training for rural youth in Vietnam to meet requirements of industrialization modernization. Retrieved from http://admin.ilssa.org.vn/UserFiles/files/AnPhamPhatHanh/Ban\%20tin\%20so\%201_E.pdf

Le, V. A. (2001). Restructuring of Northwestern rural economy in the process of industrialization and modernization (Ph.D. thesis), Ho Chi Minh National Academy of Public Administration, Hanoi.

Nguyen, T. T. T. (2012). Restructuring rural economy in Nam Dinh province in the process of industrialization and modernization. (Ph.D. thesis), National Economics University, Hanoi.

Pham, N. D. (2001). Restructuring of Industrial - Agricultural economy in the Red River Delta, current situation and solutions. (Ph.D. thesis), Ho Chi Minh National Academy of Politics, Hanoi.

Pham, N. T., \& Le, T. L. (2017). Analysis on the effects of vocational trainings on employment of rural youth in Vietnam. Retrieved from http://ilssa.org.vn/en/news/analysis-on-the-effectsof-vocational-trainings-on-employment-of-rural-youth-in-vietnam-173.

Tarp, F. (2017). Growth, Structural Transformation, and Rural Change in Viet Nam: A Rising Dragon on the Move: Oxford University Press.

Ulimwengu, J., \& Badiane, O. (2010). Vocational training and agricultural productivity: evidence from rice production in Vietnam. The Journal of Agricultural Education and Extension, 16(4), 399-411. doi:10.1080/1389224X.2010.515062. 
Wallenborn, M. (2014). Skills development for income generation in rural areas-can donors learn? Journal of International Development, 26(6), 796-809. doi:10.1002/jid.1808.

Yu, S., \& Wang, J. (2014). Factors Influencing Farmers' Willingness to Participate in the New Vocational Training. Asian Agricultural Research, 06(03), 55-59. 